\title{
CABCOCO1 Gene
}

National Cancer Institute

\section{Source}

National Cancer Institute. CABCOCO1 Gene. NCI Thesaurus. Code C116097.

This gene may play a role in the regulation of blood pressure. 